\title{
Information assets as a platform for economic growth
}

\author{
Ernest Jordan* and Janice Burn** \\ * Macquarie Graduate School of Management, Macquarie \\ University, Sydney, NSW 2109 Australia \\ Phone: +61 29850 9041; Fax: +61298509019 \\ Email: Ernest.Jordan@mq.edu.au \\ ** Edith Cowan University, Perth, Western Australia \\ Email: j.burn@cowan.edu.au
}

\begin{abstract}
The poverty of many third world countries includes the fact that they are poor in information assets. When physical assets are formally recorded they become a negotiable basis for investment, such as in the form of collateral for loans. In this sense, these are increases in information assets. One desperate need in developing countries is for the recognition of formal rights to land. In many societies, land has group ownership without any form of formal title. When properly recorded, this ownership forms the basis of an information asset - whether owned individually or collectively. Land title information systems in the developed world contribute to economic progress by enabling additional investment. The implementation of robust but state-of-the-art land title information systems would form a basis for economic development in the third world.

We further argue that there is a significant role for information technology professionals of the developed world to transfer the knowledge and skills of such, for us, bread-and-butter systems. The transfer does, however, need to be sensitive to the cultural environment of the target country. Suggestions are given about how this may be accomplished.
\end{abstract}




\section{INTRODUCTION}

The contribution of information systems and information technology to an organization are sometimes difficult to measure. Issues of competitive advantage and competitive necessity are widely discussed as are organizational responsiveness and employee productivity. The degree of difficulty of assessing the contribution increases when a community or a nation is considered. It is thus with some risk that we suggest here ways in which the world will benefit from information systems. For a starting point, we are suggesting a win-win scenario with no losers; quite different from the ideas of competitive advantage of organizations or nations, where there are winners and losers. There is the additional perspective here, which is of some concern to the thinking professional, of the responsibility that a professional has to enhancing the community that gives him/her legitimacy.

The developed world, like the Organization for Economic Co-operation and Development (OECD) member countries, has over the last twenty years been investing enormously in information technology and systems built on that technology infrastructure. Proposals for systems are typically justified in advance by cost/benefit analysis or return on investment. After implementation, the systems may be assessed for their efficiency or effectiveness or even simply for meeting the costs and benefits described at initiation. An increasing interest is displayed in the concept of white-collar productivity as a measure of the usefulness or effectiveness of a system. We discuss some of the limitations of this approach and give the case for an increased interest in the concept of the information asset.

Part of the justification for an information system can be its ability to help build an information asset, while the complement is the ability to generate a return on the asset, to put it to productive use. We examine the ability of land title information systems to add wealth to a nation and suggest ways in which the technology for such systems can be transferred to third world nations. We demonstrate a valid contribution to global development that can be made by the information technology and information systems professions.

One may wonder what contribution information technology (IT) could make to a developing economy, when the main emphases of IT are usually cost reduction, reduced employment, and increased productivity. The value of information is more important than the quantity of information. In reality, investments in information technology will only generate improved productivity if this is defined as improved effectiveness in serving internal and external customers (Davis, 1991). We show that the building of information assets is a valuable step in the development of any economy.

\section{INFORMATION ASSET}

The term information asset is suggested here as an alternative method of assessing the contribution of information technology to an organization. It will be taken to mean an off balance sheet asset derived from the accumulation of, and power to use, 
information for the organization's advantage. This is a broad definition that is nevertheless useful.

\section{The nature of information assets}

That organizations have information assets can be seen clearly enough through the concern of insurance companies to assess the risk to which they are exposed by the loss of data (Jones, 1993). The literature is overwhelmingly concerned with the safeguarding of an organization's information assets, rather than the need to put these assets to their greatest use or to find ways to increase them (Bacastow and Burns, 1991; Hansen, 1992; Menkus, 1992; Worthen, 1992; Fried, 1993). The term information asset is typically used in such cases to refer to trade secrets, copyright, and patents (Schwartz, 1990), but a wider use is also meaningful (Framel, 1990). The idea of information as an asset derives directly from thinking of information as a resource, an approach that has become widely accepted. Raw inputs to an organization can be seen to be the essential resources of materials, labour, machinery, money, and now information. Information resource management is concerned with the flows of information in organizational processes; that is, it operates at a micro level. Whenever physical resources are stockpiled they are regarded as assets; the same approach is valid for information. Thus a database is an information asset, as would be the organizational programmes and practices that support and use it.

Accountants are familiar with the concept of off balance sheet assets. Brand names and goodwill have been bought and sold, as part and parcel of a business or as assets in their own right. Like goodwill and a brand name, an information asset may need to be drastically revalued if an unforeseen or unfavourable event occurs. If information is found to be systematically incorrect, out-of-date or unreliable, the value of the asset must be written down. On the other hand, writing up the value of an information asset may well be strongly resisted. There can be an attitude that the only news is bad news. Knowing that your organization has a superior information asset to its competitors gives managers a good feeling but accepting that it is an asset, on a par with a brand name or goodwill, is often difficult (Elliott and Jacobson, 1991). At the micro level, it is easier to accept the value of information when, for instance, sales representatives are recruited because of their networks of contacts - their information assets - and will be expected to enhance them.

An organization, such as the freight company DHL, has established an information asset that is valuable. This may not show in the balance sheet but, in some circumstances, it is a more valuable business concept than productivity. The information asset may reveal itself in the price at the stock exchange. A company with rich information assets can attract a high premium on its earnings performance. Sony's purchase of entertainment archives led the way in establishing new, even higher, premiums. If resources can be accumulated and owned, then they become assets. At that point, they must then perform, that is, enable the owner to generate profits. While this is clearly true for organizations, it is also true for governments (Davies, 1992). 


\section{Measuring the effectiveness of information systems}

The contribution of an information asset to a business is twofold. First, if it is an asset then its place near the balance sheet demonstrates to the stakeholders the value of information. This is, however, very dangerous to declare explicitly. It is similar to goodwill or the value of a brand name. Both of these can disappear in a short time if goodwill becomes bad will or a brand name is exposed to negative publicity. In the same way, an organization's information asset may become inaccurate, out-of-date, unreliable or simply inferior to that of another organization. In some cases it may even be copied. It then needs to be written off just as a bank writes off bad loans (it will perhaps be done just as reluctantly). Second, the asset may generate income, profit or benefit. In this sense an asset needs to be assessed by return on investment. If it is an asset, it should produce profit. If the profit is not up to requirements then the asset may be sold, activated, downgraded or whatever.

The latter aspect is that which is referred to in leveraging the asset (Ulrich, 1990). Putting an asset to work, generating income and profits, enabling more effective competition or simply, allowing an organization to survive while competitors fail, all these are potential benefits of the information asset to an organization.

\section{Leveraging the asset - putting it into practice}

The first step has to be awareness, to make the whole organization aware of the information assets that it has and their value to the organization. This is essential in order that maintenance of its accuracy and integrity is seen as a priority. The information asset can disappear rapidly if it is unreliable. There is an increasing awareness in many organizations of the value of their information assets, such as in banks, media and entertainment organizations, travel, insurance, and related industries. The next step is to look for ways of leveraging that information. Clemons (1986) showed that sustainable competitive advantage can reliably be obtained from resources that others could not duplicate. This is most apparent in the information asset. Intimate knowledge of customers, products and transactions can be put to work through creative service development, adding support of innovation to the corporate culture and facilitating try-outs of new ideas.

While we have concentrated on organizations that are rich in information and that have a considerable information asset, there are many organizations and even countries that lack such resources. A first step in the development of such organizations can be the systematic evolution of an information asset.

\section{LAND TITLE SYSTEMS}

Land is an asset that is recognized throughout the world. In developed countries, the ability to secure formal title to land is something that we take for granted. Such titles have existed in some communities for centuries and are an inherent part of our capital and asset base. Land title systems are typically small-scale systems developed by city, province or state administrations (rather than national ones). 
They record the current owner of the land, its physical location, and any financial restraints on it, such as mortgages. In a world of high-volume, real-time transaction processing, they are not regarded as glamorous systems but very much as the bread-and-butter of local administration.

\section{Market economy and property economy}

In a penetrating and illuminating article, Hernando de Soto (1993) exposes the potential for economic development that formal title to land creates. While many politicians and economists claim that a market economy is the key to development, de Soto reveals that even with an effective market in place there is no guarantee of prosperity. In his nation, Peru, gold has been traded for centuries without building great wealth while, in the London Metal Exchange, gold futures may be traded profitably because the market place has been expanded. There is a quantum leap between selling gold nuggets and gold futures. It is this distinction that separates the market and the property economies.

Property economies recognize property rights in assets - land, gold, companies, income streams - and thereby allow instruments to be created to facilitate trade in those rights. For each asset, there is a multiplier effect as the rights generate other assets, for which new rights may be recognized. De Soto traces the most significant developments in the prosperity of nations to the creation of property rights that are formally recorded.

\section{Land title and its uses}

A formal recognition of land title shows the location, boundaries, owners and their rights. The traditional owner of land then becomes the rightful owner of land. This enables loans to be secured. Banks and others will have collateral so that default on repayments is not a complete write-off. Furthermore, there is the potential of the owner to put the asset to work. Although the traditional owner may work the land and produce income from it, there is little incentive to improve the land or to develop the property. On the other hand, an owner with title can invest in the property and multiply the value of the assets. The formal land title thus immediately enhances the asset value of the land. It is the beginning of the creation of wealth. Once the squatter becomes the rightful owner there is the incentive to maintain, invest, and develop. Their view becomes long-term, as when the squatter farmers of Australia in the nineteenth century, after their title became secure, planted trees that would take a hundred years to mature.

Of course, a major impediment to land title and land title systems is an ineffective legal system or structure. Many countries are not accustomed to the rule of law and others have legal institutions that are the playthings of the rich or powerful. Legal aspects are outside the concern of this paper, although in any realistic implementation the role of lawyers and legal institutions is primary. Information systems support and build on these legal rights, and enable the real asset to become in addition an information asset.

An additional impediment in many countries is the lack of formal maps recording land and its boundaries. The need for survey work and adjudication of rightful ownership are then paramount. 


\section{Effects of implementation of land title systems}

Land title systems in the developed world today enable administrators, developers, financiers, and owners to carry out transactions at low cost. The transaction cost view of information systems (Ciborra and Olson, 1989) simplifies the analysis of the value of information systems. Without an efficient and effective system there is a high cost of performing transactions such as the examination of rightful title, the querying of boundaries, the collection of land taxes, and so on. This transaction cost acts as a disincentive to the operation of markets. With low transaction costs all of the stakeholders can get on with their core or principal activities rather than spending inordinate amounts of time and money in establishing simple data.

\section{AN AGENDA FOR THE IT INDUSTRY}

We now suggest that the IT industry collectively has the opportunity to develop a social contribution agenda. Here the term IT industry is used in a wide sense, particularly to include information systems practitioners. It is also used internationally, to include people and organizations in all the developed world. Many national associations of professionals are affiliated to the International Federation for Information Processing (IFIP) that serves as an umbrella organization for conferences and publications. Members of the American Association for Computing Machinery (ACM), Australian Computer Society (ACS), and others are automatically covered by IFIP. It is to such an audience that this section is addressed.

\section{State of the art}

We members of the professional associations in the developed world have the state of the art in IT. We create it and put it into effect. Today's state of the art, even yesterday's, is already adequate to meet the needs of the third world in this area. Personal computers are used effectively in Canada, the United Kingdom, and elsewhere to run land title systems (Fedorko, 1993). The simple local area networks that have been in use for the last five years are quite robust and, to a great extent, debugged. Client server approaches to land title establish databases in a central office that are processed by user workstations in diverse, distributed locations (Morse, 1990; Collicott, 1992).

The experience of the Australian company BHP, now 13 years into a 20-year project in Thailand, suggests that the project management skills to implement an effective manual system may be adequate without computerization (Burns, 1993; Burns et al., 1996).

In the developed countries of the world, source data for the land title systems were manually maintained records, established decades or even centuries ago. These systems are seldom considered remarkable, except when quantum improvements are made such as with the new, open access, system implemented in London (Coltman, 1991; Baker, 1992). Our state of the art in land information systems is now way beyond simply recording ownership. It involves satellite monitoring of physical and environmental conditions, land utilization, and more 
precise measurement (Welborn, Wagner and Weber, 1990; Dueker and DeLacy, 1990; Forrest, 1991). Recreational sailors are able to monitor their position on the earth's surface to within an accuracy of 50 metres, using an affordable, reliable device. The technology is all here. What is needed is the will, skill, and ingenuity to transfer it. We do not wish to minimize legislative problems and the difficulty of deciding on rightful owners. These are indeed major hurdles, but information systems will help once these implementation tasks are completed.

\section{Technology transfer}

It is a commonplace to remark that third world countries have played technology leapfrog, where an entire generation of technology is skipped as the following one is implemented. India proceeded directly to satellite communication systems without first installing cable over the whole country. South American countries have airlines operating to remote regions that are not served by roads. Many developing nation families move directly to television communications without first using radio, or have telephones before newspapers.

We are suggesting here that third world countries can move directly to computerized land title information systems. Qualified agents include IFIP and ACM, and appropriate channels include the World Bank, United Nations agencies and government agencies such as AusAID and USAID. IFIP, ACM, ACS, the British Computer Society (BCS), and others can provide the skills, knowledge, and access to professionals.

The effects in Thailand have been dramatic, with many land transfer transactions taking place and wealth being developed (Burns et al., 1996). Not all projects have been as successful; there are many barriers to success, but success is attainable. Land owners around the third world, with title to their traditional properties will be able to invest, to develop, and to make the land productive. When they borrow money from banks, the banks' own development can continue, and the economic wheels can start to spin. The creation of an information asset can enable this. Productivity with information is of little value to the developing countries where labour costs are generally low. The metaphor for productivity is multiplication but, for asset creation, the metaphor is addition. Productivity increases multiply the small output but it remains small in world terms; asset creation adds wealth. Productivity comes next.

\section{Professionalism and empowerment}

The information technology industry has enabled business organizations to change their nature dramatically. The connections to the customer are now much closer, the awareness that organizations are interdependent has grown, and the average worker is more involved in the day-to-day business activity of the organization. The potential for empowerment of workers has been realized to only a limited extent. There has always been the ominous idea that if the system users become too knowledgeable, then our position as experts is under threat. In reality, the users are usually more interested in doing their own job than in taking over those of the systems' professionals. 
An extension of this argument applies to the development of skills and knowledge in other countries: if developing countries need information technology, let us go there, sell it to them, and look after it for them. That will establish a new market for our products and services that will add to the bottom line. What is needed instead is the development of professional skills or even just good end user skills in the developing countries. Let us help develop a new generation of professionals around the world, in the same way that the Orbis flying eye hospital travels around the developing nations, passing on skills to the local professionals. We do not need to keep this to ourselves, we can empower. This is true professionalism.

\section{CONCLUSIONS}

We have demonstrated the potential for the information technology profession to contribute to the development of the global economy, especially in the third world. International cooperative efforts could help establish land title information systems in developing countries. The injection of technology alone is inadequate; it is essential that there is a simultaneous programme for developing local personnel to support and maintain the systems. It is here that the most significant role is to be found for the information technology professional the training and support of beginning professionals in the target countries.

The effect of creating formal title to traditional lands will be to establish assets for the owners that will create a multiplier effect in the local economies. The information asset recorded in the formal title can be the starting point of a wave of economic development that is beneficial to all. The traditional emphasis of aid to the developing countries has been to assist in food production, health programmes, and infrastructure development. The information resource is one that we, in the rich world, have only recently begun to appreciate. It is one that is needed throughout the world.

\section{REFERENCES}

Bacastow, S. and Burns, R. P. (1991). Protecting the banks information asset. Bank Management, 67 (4), 44-45.

Baker, M. (1992, September). HM Land Registry - a new approach. Credit Management, 31-32.

Burns, A.F. (1993). Land Titling - the big picture paper presented at the Land Titling and Land Administration Regional Workshop, Bali, November 11-12.

Burns, A.F., Eddington, R., Grant, C. and Lloyd, I. (1996). Land Titling in Asia paper presented at the International Conference on Land Tenure and Administration, Orlando, Florida, November 1114.

Ciborra, C. U. and Olson, M. H. (1989). Encountering electronic work groups: A transaction costs perspective. Office Technology \& People, 4, 285-298.

Clemons, E. K. (1986). Information systems for sustainable competitive advantage. Information \& Management, 11, 131-136.

Collicott, G. (1992). Top man at BC systems. Canadian Datasystems, 24 (4), 36, 38.

Coltman, L. (1991, March). Land registry opens up. Credit Management, 42-43.

Davies, K. (1992). Information management in the 90s. Australian Accountant, 62 (5), 45-48.

Davis, T. R. (1991). Information technology and white-collar productivity. Academy of Management Executive, 5 (1), 55-67. 
de Soto, H. (1993, September 11-17). The missing ingredient. The Economist [Supplement The Future Surveyed], 328, 8-12.

Dueker, K. J. and DeLacy, P. B. (1990). GIS in the land development planning process: Balancing the needs of land use planners and real estate developers. Journal of the American Planning Association, 56, 483-491.

Elliott, R. K. and Jacobson, P. D. (1991). U.S. accounting: A national emergency. Journal of Accountancy, 172 (5), 54-58.

Fedorko, C. (1993). Easier access to databases, results in greater usage, higher profits. Computing Canada, 19 (4), 41, 46.

Forrest, D. (1991). Geomatics needs cooperation. Computing Canada, 17 (1), 17.

Framel, J. E. (1990). Managing information costs and technologies as assets. Journal of Systems Management, 41 (2), 12-18.

Fried, L. (1993). Distributed information security: Responsibility assignments and costs. Information Systems Management, 10 (3), 56-65.

Hansen, M. (1992). Counter-espionage techniques that work. Security Management, 36 (9), 44-52.

Jones, D. C. (1993). Computer advances create new data theft exposures. National Underwriter (PCE), 97 (24), 2, 7.

Menkus, B. (1992). Introduction to computer security. Computers \& Security, 11 (2), 121-127.

Morse, P. (1990). Metro to decentralise LIS. ComputerData, 15 (2), 1-2.

Schwartz, M. (1990). Computer security: planning to protect corporate assets. Journal of Business Strategy, 11, 38-41.

Ulrich, W. M. (1990). CASE: Full life-cycle tools from ugly legacies to artistic beauties. Software Magazine, 10 (15), 33-45.

Welborn, H., Wagner, J., and Weber, D. (1990). Trends in choosing a geographic information system. Engineering \& Management, 137 (11), 20-23.

Worthen, J. D. (1992). Protecting LAN-based information assets. Telecommunications, 26 (10), $22-$ 24. 